\title{
Justice as a Factor of Social Integrity
}

\author{
Victor V. Muravyev \\ Doctor of Philosophy, Cultural Studies Department professor of Syktyvkar State University named after P. Sorokin, \\ Syktyvkar, Russia
}

\begin{abstract}
The idea of social justice is universal for religious and secular ideologies. Sources of it may be divided in two kinds: natural and cultural. Natural sources are: laws of The Universe and human nature. Cultural sources are: holy texts and revelations, actions and teachings of holy messengers and wise men. Named sources may be combined at particular religious, moral, politic teachings and models of society organization
\end{abstract}

Keywords: wealth and poverty; justice; fair society; social equality;

\section{Introduction}

And Jesus, looking around, said to his disciples,

"How hard it will be for those who are wealthy

to enter the kingdom of God!"

Mark 10: 23

Formation of social interaction types is associated with the appearance and development of the idea of justice. The survival, stability of different societies and communities, essentially depend on reconciliation of individuals with their social status. One of main factors of social integrity is whether people evaluate their benefits and punishments as deserved. In humanitarian studies, the axiological aspects of the problem of social justice are mainly considered. Their object of investigation is why this or another type of social organization is condemned or accepted. Therefore, in humanitarian sciences the search for justice criteria is carried out. Consequently, in this field of knowledge the question of the content and sources of such criteria is central.

\section{Justice of exchange and justice of distribution}

Since ancient times, violations of the requirements of justice have caused condemnation of religious prophets and secular thinkers. Their reflections gave rise to several obvious questions. First - what is justice? Aristotle distinguished two kinds of justice: the justice of the exchange and the justice of the distribution. The fairness of exchange is the opportunity to exchange values on the basis of mutual benefit. Another type of justice is distribution according to interests, expended efforts, merits or other reasons.

Arguing about the fairness of the distribution, it is necessary to find out what we are going to distribute: material values, punishments, taxes, duties to wash dishes, night watches, rights to vote, political power or anything else. The choice of objects to share sets principles for their division. The distribution might be equalized, when everyone gets the same share. It might be not equal in this case it is necessary to determine the distribution criteria. They might be the age or sex that determine different needs of individuals, efforts expended, proximity to God, property, merits, power, race, citizenship. For example, for the distribution of punishments, the criterion of their fair distribution is the degree of harm done to society and individuals by the misconduct. Then one offender receives punishment in a form of a fine, and another - a life sentence. 


\section{Natural sources of justice}

Sources of the content of the idea of justice are divided into two types: natural and cultural. Let's consider features of different approaches to their understanding.

According to the first of them the Universe itself is arranged so that the principle of justice present in its basis (Livingston, J. C, 1993). This concept has become widespread in Indian and Chinese cultures. World laws, the ways of development of the Universe are foundations of social justice. Mo Tzu said: "Heaven certainly wants people to love each other and do each other good, but it is unpleasant for Heaven if people do each other evil, deceive each other... This is evident from the fact that Heaven adheres to universal love and brings everyone benefit "(Mo Tzu, 1994).

Wise men of ancient India believed that social divisions were generated by Rita - fundamental law of Heaven and Earth. According to The Rig Veda, four main human classes - varnas were formed from different parts of the body of the cosmic first person Purusha. Each class was prescribed a special kind of basic occupation: sacrifice, teaching, studying the Vedas for Brahmins, protection of the king's subjects for Rajanyas, cattle breeding, agriculture, commerce, usury for Vaisyas, humble service to three varnas of twice-born for Sudras. Fulfillment of these duties was considered a religious and moral duty. The class inequality was regarded as fair, since it was determined by the world order.

Followers of some religious and philosophical movements doubted the validity of the Varna system. The Mahabharata contains the reflections of the sage Bharadwaja:

"From longing, fatigue, hunger and care, sadness, fear, anger

All are not free: why should they then distinguish between varnas?"

(Mahabharata. Mokshadharma, 1969).

The idea of the spiritual equality of Varnas was advanced by Buddhism. People from different castes were accepted in Sangha and for the salvation everyone was asked to follow the same path. It was said in The Dhammapada: "I call the Brahmin one who has not committed harm either by body, word or thought - who restrains himself in three things. But I do not call a person a Brahmin only for his birth or for his mother... "(The Dhammapada, 1969).

Social divisions in Ancient China also influenced the way of life for people from different circles. All of them aspired to prosperity. Unlike India, Chinese culture always approved the achievement of worldly goods: delicious food, health, high incomes, love and recognition of others. Despite the intensive efforts aimed at obtaining them, many were not able to find what they wanted. Philosophers of China asked: why? They reflected on causes and circumstances that prevented everyone from achieving a happy life and tried to decide how to treat these circumstances. "None of the people does not desire to obtain wealth, nobility, integrity, longevity, but it has not yet happened that they have been able to avoid such misfortunes as poverty, the position of the ignoble, illness and death... It means [they] are not able to achieve what they want, "wrote Han Feizi (Han Feizi, 1994).

It turned out for Chinese thinkers that social strata membership was the very factor determined opportunities or obstacles to achieving prosperity, filling life with certain kinds of activities and events. The ideologists who expressed the views of the privileged groups asserted social differences were necessary and as natural as the existence of Heaven and Earth: "If everyone is equal, it is impossible to compel somebody to work. [Just as] there are heaven and earth, there are differences between those above and those below "(Xunzi, 1994).

Representatives of groups of higher rank, first, had the power, the right to impose their will on those who held a lower level. Secondly, they received more benefits as a result of redistribution. Third, a lifestyle of each group was characterized by a special relationship between periods of work and rest, military training and peace, physical and mental activities.

\section{Man looks for justice because of his nature}

Supporters of the second approach to social justice problem saw its sources in very nature, the essence of man. All people wanted to be happy, but they all suffered for some reason, stated Buddha. Man by his nature strived for the good, like water by its nature streamed down. People had inherent moral qualities: the ability to distinguish between good and evil, compassion, pity, shame, embarrassment. These qualities included aspiration to fight for the justice violation of its principles gave rise to resentment. This was written in the letter of the apostle Paul: "For when pagans who do not have a law do 
what is lawful by nature, then, having no law, they are their own law: they show that the work of the law is written in their hearts, as evidenced by the conscience Them and their thoughts, then blaming, then justifying one another " (The Holy Bible, 1985, Romans 2: 14-15).

The existence of an innate desire for justice was not recognized by all. One of the directions of religious and philosophical anthropology was the doctrine of the evil nature of man. As noted by Z. Freud, E. Durkheim and other researchers, innate human unconscious hostility toward neighbors, fear and a sense of helplessness, aggression, manifestations of sexual instinct had to be limited and modified by the impact of early magical rituals and prohibitions aimed at maintaining social justice (Freud, Z, 1997).

Increasing property and social inequality had become a psychic irritant since historic period of civilization formation. Intensive daily work, dictated by the need to support families and serve state duties, filled the lives of most people. Chinese historian Ban Gu wrote about the farmers: "In the spring they have nowhere to hide from the wind and dust, in summer from the heat, in the fall - from the rain, in the winter - from the cold. For all four seasons there is not one day, when they could rest. Moreover, they still see off and meet relatives, commemorate the dead and care for the sick, feed the seniors and care about young generations. Such are their tireless work and the hardships of life "(Ban Gu, 1980).

The Chinese "lower classes" criticized social order because of which some people worked daily, struggling out of their might, while others indulged in idleness and entertained themselves:

"Some have rest they live, having fun at feasts,

Others serve the country, languishing in labor.

Some people rest in their beds,

Others are in their endless way being in the cold and in the mud."

(Shi Jing, 1994).

Followers of different Chinese philosophy schools shared the idea human well-being should correspond to persons social utility. Mo Tzu, Confucius, Shang Yang, Xunzi offered to nominate talented people to positions of responsibility irrespective of their origin.

Ancient Chinese teachers of wisdom talked about the need for a combination of mental and physical labor: "The wise [ruler] must work to farm the land with subject people prepare food for himself and at the same time rule" (Mencius, 1994). Mo Tzu believed emperors and other notable people demonstrated immorality, lack of philanthropy, enjoying music and contemplating combat exercises while most people suffered immensely and were sick because they had no rest (Mo Tzu, 1994). The past millennia did not change the distribution structure in principle. P. Sorokin asked in XX century: "Is not life still a sole feast for some, and Golgotha, torture, continuous labor and poverty for others?" (Sorokin, 1992).

The basis of appeals for social justice was the principle of equality. If people were equal by nature, then justice consisted in establishing a system of equal distribution of material and spiritual values, political rights, opportunities for rest and entertainment, possibilities to follow own moral convictions and receive approval and recognition of others.

At the same time, within the framework of the second approach to the problem of sources of justice, there was a teaching that people are not equal by their nature. Humans are endowed with different qualities, abilities and Therefore, their values for society are not the same. Discussing egalitarianism ideas, their opponents expressed fears that an emperor in agrarian field or in a pigsty would become tired after a few attempts to do something. A peasant waking up in the morning on a soft fluff and accepting as an offering orchids and tangerines would begin to yearn and worry and the temperature of his body would rise in unaccustomed conditions and cause his illness. Concerns about state affairs require efforts and time not less than works of grain grower: "That's why those who are busy thinking about plans do not participate in practical activities and those who personally [engage in] practical activities do not determine the principles of [governing the country] " (Guanzi, 1994). Consequently, in the world of people, an unequal distribution of public goods was fair. If today some individuals spend days of their life somewhere in the "Earthly Eden", connected with the ordinary world only by the road to the international airport, it fairly corresponds to their outstanding qualities. 
In European philosophy, the doctrine of social justice was developed within the framework of materialistic anthropology. Proceeding from the idea of equality, Helvetius argued that every act was correct to the extent that it helped to achieve the greatest possible happiness for as many people as possible. In search of ways to achieve this kind of happiness, Marx formulated principles of the reorganization of society. Considering, like Buddha, that the life of most of humanity was suffering, he saw the causes of suffering in unjust property distribution. To save people from suffering, it was necessary to carry out a radical redistribution of material values, taking away property from those who satisfy their needs at the expense of others. Marx declared as utopia a plan for the rich to voluntarily give the poor and hungry some of their benefits, feeling compassion and remorse. The noble extreme way of establishing social justice was forcible it was the revolution of destitute people. Within the first socialist phase of a new society, the share of benefits received by able-bodied individuals would be determined by their labor contribution, and then, at the actual communist stage of development, everything would be given according to needs simply by virtue of belonging to the human race.

\section{Embodiments of justice}

The third source of the idea of social justice were lives and deeds of heroes dedicated to it, envoys of higher forces, teachers, sages, high - minded men who served as justice embodiment and model. Confucius, Prophet Mohammed, Jesus Christ being founders of the influential religions did not write down their teachings themselves, inspiring followers with sermons and instructive actions: "And Jesus walked throughout Galilee, teaching in their synagogues and preaching the gospel of the Kingdom and healing all disease and infirmity in people" (The Holy Bible, 1985, Matthew 4: 23, 25). Personal qualities of the messengers: devotion to Allah, active actions, the struggle for faith of the Prophet Mohammed, Moses sacred obsession and devotion to his people, Jesus love for any neighbor, compassion, faith, hope, strength of spirit, meekness, peace, sorrow, detachment from the worldly, made up the moral ideals of Islam, Judaism and Christianity.

Confucius proposed to build life in accordance with selected values. "High - minded man" was different from "mean people" not by material property or special origin, but because he was a man of life style of justice. Many Chinese scholars, left out of work, returned to their native villages and led a poor, solitary life. But they had a status different from the position of ordinary villagers, because they lived a life chosen voluntarily, and not given by circumstances. Confucius admired them: "To eat usual food, drink water, sleep, putting your hand under your head - these are also pleasures. The wealth and nobility received dishonestly for me are like clouds floating in the sky "(Lun Yu, 1994).

Confucius understood high - minded personal image, philanthropy might be feigned. Such pretended image ruined in periods of difficulties and dangers. Weak person forgot high values and his behavior was guided by fear and concern for own benefit. Therefore, the Honored Teacher called his followers to always be ready for hard trials, not to "lose face", not to do to others, which they did not want for themselves: "A high - minded man, falling into poverty, endures it stubbornly. The mean man, falling into difficulties degrades "(Lun Yu, 1994).

\section{Justice in Holy Revelations}

The fourth source of social justice principles had foundations in revelations of Higher Forces, given in oral traditions and sacred texts. Religious people tended to observe moral principles and norms if they considered them to be approved from above. Violations of justice norms produced emotions of guilt, shame, need for redemption.

The doctrine of early Christianity arose as a religion of people deprived of well-being, strangers in the Holiday of life. The Bible testifies that the first Christian communities were communistic, based on the principles of community of property: "... and not one of them claimed that anything belonging to him was his own; but all things were common property to them" (The Holy Bible, 1985, Acts 4: 32). Jesus plainly declared: "...it is easier for a camel to go through the eye of a needle than for a rich man to enter the kingdom of God" (The Holy Bible, 1985, Mt. 19: 24). As we know, in the earliest of the surviving texts of the Gospel of Luke, Christ began "The Beatitudes" with the words "Blessed are you who are poor for yours is the kingdom of God" (The Holy Bible, 1985, Luke 6: 20).

Probably in later interpretations this statement was changed to famous words "Blessed are the poor in spirit" (The Holy Bible, 1985, Matthew 5: 3). As a result, the meaning of the subsequent reasoning of Jesus, based on the comparison of controversial concepts was lost. Originally it was based on mental approach when in the content of one idea there were signs excluded from the contents of the other and replaced by opposite characteristics: beggars-rich, hungry-satiated, crying-laughing. Obviously, Christ spoke to the hearers preaching: "Blessed are the poor, for yours is the kingdom of God." Blessed are you who hunger now, for you shall be satisfied. Blessed are you who weep now, for you shall laugh..." (The 
Holy Bible, 1985, Lk 6: 20 - 21). And in contrast to it: "But woe to you who are rich, for you receiving your comfort in full. Woe to you who are well - fed now, for you shall be hungry. Woe to you, who laugh now, for you shall weep and mourn "(The Holy Bible, 1985, Lk. 6: $20-21,24-26)$. There is an impression that Pope Francis had chosen the help of all dispossessed, not only Christians, as leading the principle of his ministry. Perhaps this was a kind of new left doctrine, formed in conditions of weakening the influence of secular communist ideology.

Turning to the question of the consequences of observing or violating the principles of justice in religious moral codes, we find two types of ethics. In teleological ethics, there was the hope of Otherworld reword for observing the norms of justice and the fear of the punishment for violating them: "... if somebody loves people and benefits them Heaven will certainly make him happy. And he who creates evils for people, deceives people, Heaven will certainly punish "(Mo Tzu, 1994). Deontic ethics was based on the idea of duty, for it justice was a reward itself. The man was satisfied, calmed because of realization of his duty: "A high - minded man knows only duty, a mean man knows only his benefits" (Lun Yu, 1994).

The Muslim ethical system was teleological. The hadith of the Sunna from Abdullah bin Umar / Sahih al-Bukhari stated that anyone who helps his brother in need, Allah would help in his own need, anyone who protects the Muslim from the misfortune, Allah would protect from hardships on the Day of Judgment.

As a criterion for the fairness of the distribution of material values in Islam, the basic vital needs of man were chosen. Islam did not share the radical ideas of Christ and K. Marx about community of the property. Muslims were obliged to help everyone in the worst conditions. But the fact that people were not equal in welfare was an inevitable reality: "Do not look at what We have given some of them to subject them to this temptation. It is the glitter of earthly life, and the destiny of your Lord is better and more durable "(The Qur'an, 2001). At the same time, there was basic level, below which no one should fall. To maintain it there was the zakat.

Islam allowed a real possibility of establishing justice in social relations. The Muslim ethic called upon believers to take active efforts aimed at social transformation. The world was not perfect, but it was the creation of the Most High. Therefore, it was necessary to improve it, to bring it in line with sacred principles.

\section{Conclusion}

Sources of the content of the idea of justice in human history were divided in two types: natural and cultural. Natural sources were: a) world laws; b) the nature of man. To the second type belong: c) exemplary acts of outstanding personalities, examples of the life of heroes, sages, prophets; d) sacred revelations transmitted orally or in texts. It should be noted that in complex ideologies, a combination of these sources was possible.

Reflections on social justice, interpretations of its content in various cultures, and real attempts to affirm it confirmed the truth of the judgments of Henri de Saint-Simon. He believed the organization of a society that gave all individuals greatest amount of happiness was the most important and at the same time most difficult problem to solve ever faced by people.

\section{References}

[1] Aristotle, 1984, Politics, in Aristotle Collected works in 4 volumes - Moscow: Thought, Volume 4, 375 - 645

[2] Ban Gu, 1980, Review of the laws, in M. A. Korostovtsev, I. S. Katsnelson, V. I. Kuzishchin (eds) Reader on the history of the Ancient East, in 2 parts, Moscow: High School, Part 2, 185 - 189

[3] Guanzi, 1994, in Ancient Chinese philosophy, in 2 volumes, Moscow: PrintT, Volume 2, 14 - 57

[4] The Dhammapada, 1969, in Anthology of World Philosophy, in 4 volumes, Moscow: Thought, Volume 1, Part 1, $129-133$

[5] The Holy Bible, 1985, Nashville, Tennessee: Holman Bible Publishers / Scriptures were taken from the NEW AMERICAN STANDARD BIBLE, 1977, by The Lockman Foundation. Used by permission.

[6] The Qur'an, 2001/ Translation by I. Y. Krachkovsky, Rostov - on - Don: Phoenix

[7] Lun Yu, 1994, in Ancient Chinese philosophy: in 2 volumes, Moscow: PrintT, Volume 1, 139 - 174

[8] Mahabharata. Mokshadharma, 1969, in Anthology of World Philosophy: in 4 volumes, Moscow: Thought, Volume 1, Part 1, 107- 114

[9] Mo Tzu, 1994, in Ancient Chinese philosophy: in 2 volumes, Moscow: PrintT, Volume 1, 175 - 200

[10] Mencius, 1994, in Ancient Chinese philosophy: in 2 volumes, Moscow: PrintT, Volume 1, 225 - 247 
[11] Sorokin, P, A, 1992, The problem of social equality, in Sorokin P. A. Man. Civilization. Society, Moscow: Politizdat, 245 - 265

[12] Xunzi, 1994, in Ancient Chinese philosophy, in 2 volumes, Moscow: PrintT, Volume 2, 141 - 209

[13] Freud, Z, 1997, Totem and the Taboo, St. Petersburg: Aleteya

[14] Han Feizi, 1994, in Ancient Chinese philosophy, in 2 volumes, Moscow: PrintT, Volume 2, 224 - 283

[15] Shi Jing, 1994, in Ancient Chinese philosophy, in 2 volumes, Moscow: PrintT, Volume 1, 78 - 99

[16] Livingston, J. C, 1993, Anatomy of the Sacred. An Introduction to Religion, New York: Macmillan Publishing Company 